\title{
PERBANDINGAN MODEL INDEX CARD MATCH DENGAN TIME TOKEN ARENDS TERHADAP KETERAMPILAN BERBICARA SISWA KELAS V SDN CARINGIN III KABUPATEN TANGERANG
}

\author{
Rini Rindayani ${ }^{1}$, Dilla Fadhillah ${ }^{2}$ \\ Universitas Muhammadiyah Tangerang \\ rinirindayani96@gmail.com ${ }^{1}$ \\ dillafadhillah@umt.ac.id ${ }^{2}$
}

\begin{abstract}
ABSTRAK
Penelitian ini bertujuan untuk mengetahui perbandingan Model Index Card Match Dengan Time Token Arends terhadap keterampilan berbicara dengan mata pelajaran Bahasa Indonesia siswa kelas V SDN Caringin III Kabupaten Tangerang. Metode penelitian ini adalah quasi eksperimen jenis Nonquivalent Control Group Desaign. Hasil dari uji validitas isi dengan uji pakar Bahasa Indonesia. Sebelum data analisis, terlebih dahulu di uji persyaratan yaitu uji normalitas dengan menggunakan Chi Kuadrat dan uji Homogenitas dengan menggunakan uji Fisher. Uji Normalitas untuk kelas eksperimen 1 diperoleh $t_{\text {hitung }} 2,0041<t_{\text {tabel }} 11,07$ sedangkan untuk kelas eksperimen $2 t_{\text {hitung }} 1,1662<t_{\text {tabel }} 11,07$ maka dapat disimpulkan bahwa kedua kelas sampel diperoleh dari populasi yang berditribusi normal. Hasil perhitungan uji homogenitas diperoleh $F_{\text {hitung }} 1,27$ sedangkan $F_{\text {tabel }} 1,84$ hal ini berarti Hasil perhitungan uji homogenitas diperoleh $F_{\text {hitung }} 1,07<$ $F_{\text {tabel }} 1,84$ hal ini berarti populasi dari kedua data memiliki varians yang homogen. Pengujian statistik dengan menggunakan uji t pada taraf signifikan 0,05 diperoleh uji $t_{\text {hitung }}$ 1,76 sedangkan $\mathrm{t}_{\text {tabel }} 2,00$. Karena $\mathrm{t}_{\text {hitung }}$ lebih kecil dari $\mathrm{t}_{\text {abel }} 1,76<\mathrm{t}_{\text {tabel }} 2,00$ maka $\mathrm{H}_{0}$ diterima dan $\mathrm{H}_{1}$ ditolak. Dengan demikian tidak terdapat Perbandingan Antara Model Index Card Match Dengan Time Token Arends. Akan tetapi dilihat dari rata-rata kelas eksperimen 1 yaitu 75,06 dan kelas eksperimen 2 yaitu 70,71. Melihat hasil dari nilai rata-rata postes kelas eksperimen 1 yang menggunakan model Index Card Match lebih baik daripada kelas eksperimen 2 yang menggunakan model Time Token Arends. Terhadap Keterampilan Berbicara Siswa Kelas V SDN Caringin III Kabupaten Tangerang.
\end{abstract}

Kata Kunci : Model ICM, TTA, Keterampilan Berbicara.

\section{A. PENDAHULUAN}

Pendidikan tidak hanya dipandang sebagai usaha pemberian informasi dan pembentukan keterampilan saja, namun diperluas sehingga mencakup usaha untuk mewujudkan keinginan. Kebutuhan dan kemampuan individu sehingga tercapai pola hidup pribadi dan sosial yang memuaskan. Pendidikan bukan semata-mata sebagai sarana untuk persiapan kehidupan yang akan datang, tetapi untuk kehidupan anak sekarang yang sedang mengalami perkembangan menuju ke tingkat kedewasaannya. Sekolah merupakan lembaga profesional yang menaungi masalah pendidikan. Sekolah bertujuan membentuk anak didik menjadi manusia dewasa yang 
berkepribadian matang dan tangguh, yang dapat dipertanggungjawabkan dan bertanggung jawab terhadap masyarakat dan terhadap dirinya.

Mata pelajaran Bahasa Indonesia merupakan salah satu bidang studi yang diajarkan di sekolah. Bahasa Indonesia dijadikan sebagai wadah untuk mengasah keterampilan berbicara siswa. Oleh karena, mata pelajaran Bahasa Indonesia memilik empat aspek yaitu, menyimak, berbicara, membaca, dan menulis. Di dalam pelajaran Bahasa Indonesia keempat aspek tersebut wajib dikuasi oleh siswa salah satunya yaitu keterampilan berbicara, dengan adanya keterampilan berbicara siswa bisa mampu mudah dalam berbicara, tidak terbata-bata pada saat berbicara di depan kelas. Keterampilan berbicara adalah keterampilan berbahasa yang berkembang pada kehidupan anak yang didahului oleh keterampilan menyimak, pada masa ini kemampuan berbicara atau berujar dipelajari (Tarigan, 2015:3). Keterampilan berbicara masih berhubungan erat dengan perkembangan kosa kata yang diperoleh oleh anak. Oleh karena, berbicara merupakan keterampilan dalam menyampaikan pesan melalui bahasa lisan kepada orang lain. Perlu kita sadari bahwa keterampilan diperlukan bagi kegiatan berbicara yang efektif dikehidupan sehari-hari.

Berdasarkan hasil pengamatan dengan wali kelas V di SDN Caringin III Kabupaten Tangerang mengenai Keterampilan Berbicara pada pembelajaran Bahasa Indonesia, dapat diketahui rendahnya keinginan siswa untuk berbicara dalam proses belajar jika diberikan tugas oleh guru. Hal tersebut kurangnya perhatian guru kepada siswa pada saat pelajaran berlangsung di kelas, kurangnya percaya diri dalam berbicara di depan kelas, karena kurangnya model pembelajaran yang bervariasi dan kurangnya menggunakan media sehingga siswa kurang terampil dalam berbicara. Untuk mengatasi masalah tersebut diperlukan model pembelajaran yang dapat meningkatkan keterampilan berbicara. menggunakan model index card match dan time token arends terhadap keterampilan berbicara siswa agar proses kegiatan belajar mengajar di kelas lebih menyenangkan dan membuat siswa lebih aktif, dan cepat menyerap materi yang diberikan. Index card match membuat potongan-potongan kertas sebanyak jumlah siswa, bagilah kertas-kertas tersebut menjadi dua bagian yang sama. Pada separuh bagian, ditulis pertanyaan tentang materi yang akan dipelajari. Setiap kertas berisi satu pertanyaan. Pada separuh kertas yang lain, tulis jawaban dari pertanyaan-pertanyaan yang telah dibuat, kemudian campurkan antara soal dan jawaban. Setiap siswa di beri satu kertas. Separuh siswa akan mendapatkan soal dan separuh yang lain akan mendapatkan jawaban. Kemudian siswa mencari pasangan, setelah 
semua siswa menemukan pasangan dan duduk berdekatan, mintalah kepada setiap pasangan secara bergantian untuk membacakan soal yang di peroleh, selanjutnya soal tersebut dijawab oleh pasangannya dan akhiri proses ini dengan membuat kesimpulan.

Sedangkan time token arends dibuat beberapa kelompok, kemudian diberikan beberapa kupon bicara kepada masing-masing kelompok, kemudian setiap siswa yang mau berbicara memberikan kartu bicaranya, Siswa yang telah habis kuponnya tak boleh bicara lagi, yang masih memegang kupon harus bicara sampai kupon nya habis. Berdasarkan paparan latar belakang di atas, maka peneliti akan melakukan penelitian tentang model pembelajaran yang berpotensi membuat siswa sebagai pusat pembelajaran. Penelitian yang berjudul : "Perbandingan Antara Model index card match Dengan time token arends Terhadap Keterampilan Berbicara Siswa Kelas V SDN Caringin III Kabupaten Tangerang”.

\section{B. KAJIAN TEORI}

Pada keterampilan berbicara menunjang keterampilan bahasa lainnya. Pembicara yang baik mampu memberikan contoh agar dapat ditiru oleh penyimak yang baik (Sujinah, 2017:1). Tujuan berbicara yaitu untuk berkomunikasi dengan baik agar bisa menyampaikan secara efektif. Pembicara harus memahami makna suatu yang ingin dibicarakan untuk disampaikan apa yang akan dibicarakan kepada pendengar. Keterampilan berbicara juga bukan hanya memahami tetapi dia juga harus lantang dalam mengucapkan bunyi-bunyi atau kata-kata.

Keterampilan berbicara hakikatnya keterampilan memproduksi arus sistem bunyi artikulasi untuk menyampaikan kehendak, kebutuhan perasaan, dan keinginan kepada orang lain. Alat ucap seseorang merupakan persyaratan yang alamiah dalam suatu ragam bahasa. Dari keterampilan ini juga didasari oleh kepercyaan dari diri sendiri untuk terampil dalam berbicara dengan baik dan benar. Dengan demikian agar terampil dalam berbicara hilangkan rasa malu, rendah diri dan berat lidah.

Menurut Silberman (2013:250), "Index Card Macth (ICM) merupakan cara aktif dan menyenangkan untuk meninjau ulang materi pelajaran, cara ini memungkinkan siswa untuk berpasangan dan memberi pertanyaan kuis kepada temannya”. Demikian mencocokkan kartu indeks ini suatu cara yang aktif dan menyenangkan untuk mempelajari kembali materi pelajaran. Dengan cara ini, dapat membuat siswa bekerjasama dalam menjawab pertanyaan dengan 
mencocokkan kartu yang ada di tangannya. Dalam proses pembelajaran ini lebih menarik karena siswa mencari pasangan sambil belajar dalam suasana yang menyenangkan.

Menurut Sohimin (2014:216), "Time Token Arends (TTA) adalah salah satu tipe pembelajaran kooperatif, siswa dibentuk ke dalam kelompok belajar, yang dalam pembelajaran ini mengajarkan keterampilan sosial untuk menghindari siswa mendominasi pembicaraan atau menghindarkan siswa diam sama sekali dalam berdiskusi. Dengan demikian dalam pemilihan materi harus sesuai dengan model time token arends dan menekankan pada penyampaian pendapat siswa. Hal ini lebih dominan pada keaktifan siswa dalam mengutarakan pendapatnya. Dalam pemahaman tentang materi, siswa diutamakan dalam bentuk diskusi.

\section{METODOLOGI}

Penelitian ini dilakukan dengan metode eksperimen semu (quasi eksperiment). Penelitian dilaksanakan di SDN Caringin III Kabupaten Tangerang Tahun Pelajaran 2017/2018. Populasi penelitian adalah kelas V yang berjumlah 64 siswa. Adapun sampel penelitian terdiri dari dua kelas yaitu kelas VA dan VB masing-masing kelas terdiri dari 32 siswa. Teknik pengambilan sampel dengan teknik Sampling Jenuh. Menurut Sugiyono (2016), "Dikatakan Sampling Jenuh adalah teknik penentuan sampel bila semua anggota populasi digunakan sebagai sampel". Data dalam penelitian ini berupa hasil tes keterampilan berbicara pada materi drama yang terdiri dari 1 soal keterampilan berbicara untuk melihat perbedaan dari kelas eksperimen 1 dan kelas eksperimen 2. Maka baik kelas eksperimen 1 maupun kelas eksperimen 2 diberikan pretes dan postes. Untuk pretes dan postes digunakan perangkat tes yang sama, tetapi untuk diberi perlakuan diberikan tes yang berbeda. Data hasil penelitian yang diperoleh selanjutnya dianalisis statistik deskriptif dan inferensial. Pengujian terhadap perbedaan rata-rata hasil postest menggunakan teknik statistik uji t test.

\section{PEMBAHASAN}

Soal-soal yang telah dibuat oleh peneliti, terdiri dari 1 soal yang sudah di uji oleh pakar ahli yaitu pada dosen Bidang Mata Kuliah Bahasa Indonesia di Universitas Muhammadiyah Tangerang, indikator yang berasal dari buku Sumber: Sujinah (2017), dapat di lihat sebagaimana pada Tabel 1. 
Tabel 1. Distribusi Indikator Keterampilan Berbicara

\begin{tabular}{|c|c|c|c|c|}
\hline \multirow[t]{2}{*}{ Variabel } & \multirow[t]{2}{*}{ Kompetensi Dasar } & \multirow[t]{2}{*}{ Indikator } & $\begin{array}{l}\text { Bentuk } \\
\text { Soal } \\
\end{array}$ & \multirow[t]{2}{*}{$\begin{array}{l}\text { Nomor } \\
\text { Item }\end{array}$} \\
\hline & & & Essay & \\
\hline \multirow[t]{2}{*}{$\begin{array}{l}\text { Keterampilan } \\
\text { Berbicara }\end{array}$} & \multirow{2}{*}{$\begin{array}{l}\text { 6.2 Memerankan tokoh } \\
\text { drama dengan lafal, } \\
\text { intonasi, dan } \\
\text { ekspresi yang tepat }\end{array}$} & $\begin{array}{l}\text { 6.2.1 Membaca } \\
\text { drama pendek } \\
\text { dengan } \\
\text { lancar dan jelas. }\end{array}$ & \multirow[t]{3}{*}{ Praktek } & 1 \\
\hline & & $\begin{array}{l}\text { 6.2.2 Memerankan drama } \\
\text { pendek dengan } \\
\text { lantang, gerak-gerik, } \\
\text { rasa percaya diri, } \\
\text { dan ekspresi yang } \\
\text { sesuai karakter } \\
\text { tokoh. }\end{array}$ & & 1 \\
\hline \multicolumn{3}{|c|}{ Jumlah Total Butir } & & 2 \\
\hline
\end{tabular}

Setelah soal diuji oleh ahli pakar, semua soal layak digunakan dan telah memenuhi syarat validasi. Selanjutnya tes tersebut digunakan dalam penelitian. Hasil dari data penelitian kemudian diuji normalitas dan uji homogenitas, dan hasilnya dinyatakan memenuhi syarat normal dan homogen. Sehingga dapat dilakukan pengujian hipotesis terhadap tes keterampilan berbicara. Secara deskriptif data pretest dan postest untuk keterampilan berbicara dapat dilihat pada berikut:

Tabel 2. Hasil Analisis Deskriptif Pretest dan Postest Keterampilan Berbicara Kelas Eksperimen 1 dan Eksperimen 2

\begin{tabular}{|c|c|c|c|c|c|c|c|c|}
\hline & Kelas & $\mathbf{N}$ & Min & Max & Mean & Modus & Median & SD \\
\hline Pretes & Eksperimen & \multirow{2}{*}{32} & 40 & 80 & 60,71 & 63,3 & 54,41 & 117,28 \\
\cline { 4 - 9 } & 1 & & 55 & 95 & 75,06 & 74,1 & 65,42 & 95,06 \\
\hline Postes & 1 & & 45 & 85 & 63,75 & 63,12 & 56,75 & 91,77 \\
\hline Pretes & Eksperimen & \multirow{2}{*}{32} & 50 & 90 & 70,71 & 68,75 & 63,5 & 102,01 \\
\hline Postes & 2 & & 50 & &
\end{tabular}

Berdasarkan Tabel 2, nilai pretest pada kelompok eksperimen 1 menunjukkan nilai minimum 40 dan maksimum 80 dan untuk nilai postest menunjukkan nilai minimum 55 dan maksimum 95. Kelompok eksperimen 2 nilai pretest menunjukkan nilai minimum 45 dan maksimum 85 dan untuk nilai postest menunjukkan nilai minimum 50 dan maksimum 90. Sehingga dapat disimpulkan nilai pretest lebih baik di eksperimen 2 sedangkan nilai postest lebih baik di eksperimen 1. Hal ini dapat dilihat pada Tabel 3 : 
Tabel 3. Ringkasan nilai pretest dan postest

\begin{tabular}{|c|c|c|}
\hline Kelas & Rata-rata nilai pretes & Rata-rata nilai postes \\
\hline Eksperimen 1 & 60,71 & 75,06 \\
\hline Eksperimen 2 & 63,75 & 70,71 \\
\hline
\end{tabular}

Pada Tabel 3, menunjukkan bahwa kelas eksperimen 2 lebih tinggi dari eksperimen 1, kedua kelas tergolong dalam kategori sedang. Berdasarkan hasil analisis uji t pada variabel keterampilan berbicara. Antara kelompok eksperimen 1 dan eksperimen 2 ditunjukkan pada Tabel 3.

Tabel 4 Uji-t Tes Akhir Keterampilan Berbicara

Kelas Eksperimen 1 dan Eksperimen 2

\begin{tabular}{|c|c|c|}
\hline \multirow{2}{*}{ Uji-T } & $\mathbf{T}_{\text {hitung }}$ & $\mathbf{T}_{\text {tabel }}\left(\mathbf{1}-\frac{\boldsymbol{\alpha}}{\mathbf{2}}\right)^{\mathbf{t}}\left(\mathbf{n}_{\mathbf{1}}+\mathbf{n}_{\mathbf{2}}-\mathbf{2}\right.$ \\
& & $\mathbf{2})$ \\
\cline { 2 - 3 } & 1,76 & 2,00 \\
\hline
\end{tabular}

Berdasarkan tabel 4 , menunjukkan nilai $t_{\text {hitung }}(1,76)$ pada taraf signifikan $\alpha=0,05$. Dari hasil perhitungan tersebut diperoleh $t_{\text {hitung }}(1,76)<(2,00) t_{\text {tabel }}$, maka hipotesis penelitian $\mathrm{H}_{0}$ diterima dan hipotesis $\mathrm{H}_{1}$ ditolak, maka tidak terdapat perbedaan keterampilan berbicara dengan materi drama yang diberi model Index Card Match dengan Time Token Arends. Untuk mengetahui terdapat atau tidaknya perbedaan rata-rata skor yang diperoleh dan mengetahui lebih baik menggunakan ICM atau TTA dapat dilakukan pengujian hipotesis data dan menunjukkan bahwa terdapat perbedaan rata-rata skor yang diperoleh yang diberikan model Index Card Match (ICM) yaitu rata-ratanya 75,06 sedangkan siswa yang diberi model Time Token Arends (TTA) yaitu rata-ratanya 70,71. Dengan melihatnya dari rata-rata maka menggunakan model Index Card Match (ICM) lebih baik daripada siswa yang belajar dengan menggunakan model Time Token Arends (TTA).

Meskipun model Index Card Match lebih baik daripada Time Token Arends (TTA), namun masih ada beberapa kendala yang dialami pada saat penelitian berlangsung, dikelas eksperimen 1 maupun kelas eksperimen 2 yang sebelumnya dalam pembelajaran dikelas siswa masih kurang percaya diri. Pada model Index Card Match dan Time Token Arends ini siswa yang harus lebih banyak terlibat dalam pembelajaran, serta setiap siswa diberikan kesempatan untuk 
berbicara di depan kelas. Dengan demikian, peneliti perlu untuk mempersiapkan waktu yang cukup lama dan juga bahan ajar yang mudah dimengerti dan menarik bagi siswa sehingga dapat membangkitkan semangat untuk belajar dan aktif dalam pembelajaran yaitu salah satunya dengan memberikan reward kepada siswa serta menghargai setiap pekerjaan yang telah siswa lakukan.

\section{E. KESIMPULAN}

Hasil penelitian dapat disimpulkan bahwa hasil perhitungan uji hipotesis dengan uji-T didapat perhitungan bahwa $t_{\text {hitung }}=1,76$ sedangkan $t_{\text {tabel }}=2,00$ dengan demikian $t_{\text {hitung }}<t_{\text {tabel }}(\alpha=$ 0,05), maka $\mathrm{H}_{0}$ diterima dan $\mathrm{H}_{1}$ ditolak. Hal itu menunjukan bahwa tidak adanya perbedaan hasil antara kelas eksperimen 1 dan kelas eksperimen 2. Akan tetapi dilihat dari rata-rata kelas eksperimen 1 yaitu 75,06 dan kelas eksperimen 2 yaitu 70,71. Dari nilai rata-rata postes kelas eksperimen 1 yang menggunakan model Index Card Match lebih baik daripada kelas eksperimen 2 yang menggunakan model Time Token Arends.

Berdasarkan hasil penelitian yang telah dilakukan, menunjukkan bahwa tidak terdapat perbedaan kelas eksperimen 1 dan kelas eksperimen 2 terhadap keterampilan berbicara pada siswa kelas V. Akan tetapi pada saat penerapan pembelajaran di kelas dengan menggunakan model tersebut dapat membuat siswa lebih aktif dan termotivasi dalam belajar, karena pembelajaran yang dilakukan lebih banyak melibatkan siswa di dalamnya sehingga siswa lebih mudah paham terhadap materi pelajaran yang diberikan, dan tidak ada siswa yang diam sama sekali pada saat proses pembelajaran berlangsung. Model Index Card Match dan Time Token Arends dapat diterapkan di kelas oleh guru untuk memberikan variasi pada proses pembelajaran agar pembelajaran tidak cepat terasa bosan.

\section{F. DAFTAR PUSTAKA}

Shoimin Aris. (2014). 68 Model Pembelajaran Inovatif dalam Kurikulum 2013. Yogyakarta: ArRuzz Media.

Silberman, Melvin L. (2013). Active Learning 101 Cara Belajar Siswa Aktif. Bandung: Nusamedia \& Nuansa Cendekia.

Sujinah. (2017). Menjadi Pembicara Terampil. Yogyakarta: Deepublish.

Sugiono. (2016). Metode Penelitian Kuantitatif, Kualitatif, dan R\&D. Bandung: Alfabeta.

Tarigan, Henry Guntur. (2015). Berbicara Sebagai Suatu Keterampilan Berbicara. Bandung: Aangkasa Bandung. 